\title{
Cellular Premixed Flames of Synthetic Biogas Composition Effects on Flat Burner
}

\author{
Amornrat Kaewpradap ${ }^{1, *}$, Annop Noppharatana ${ }^{2}$, and Sumrerng Jugjai ${ }^{1}$ \\ 1 Combustion and Engine Research Laboratory (CERL), Department of Mechanical Engineering, \\ Faculty of Engineering, King Mongkut's University of Technology Thonburi, Thailand \\ 2 Pilot Plant Development and Training Institute, King Mongkut's University of Technology Thonburi, \\ Thailand \\ *E-mail: amornrat.kae@kmutt.ac.th (Corresponding author)
}

\begin{abstract}
To compare the effects of biogas compositions, cellular premixed flames of synthetic biogas on flat burner was investigated. As the variation of main composition of biogas such as methane $\left(\mathrm{CH}_{4}\right)$ and carbon dioxide $\left(\mathrm{CO}_{2}\right)$, the biogas produced from agricultural waste (54.9:45.1), food waste (73.4:26.6) and cow dung (85.1:14.9) were used to investigate for this study. Moreover, the lean combustion system was experimented on flat burner to reduce the greenhouse gases. The variation of equivalence ratio between $\Phi=0.65-1.00$ and firing rate with $45 \mathrm{~L} / \mathrm{min}$ of mixture flow rates were studied. The results showed the cellular flame from agricultural waste, food waste and cow dung were found between $\Phi=0.75-1.00, \Phi=0.70-0.90$ and $\Phi=0.65-0.80$, respectively. In addition, the blown off flames were also observed at $\Phi<0.75, \Phi<0.70$ and $\Phi<0.65$ from agricultural waste, food waste and cow dung compositions, respectively. The results showed the variation of biogas compositions, equivalence ratio and firing rate affected to cellular flames owing to the intrinsic instability. Moreover, it was concluded that small cell size, higher light emission and narrower unstable range and wider flame range obtained in the combustion of biogas produced from cow dung composition, was more stable compared to biogas from agricultural waste and food waste compositions.
\end{abstract}

Keywords: Cellular premixed flame, synthetic biogas, intrinsic instability, flat burner.

ENGINEERING JOURNAL Volume 21 Issue 7

Received 1 September 2017

Accepted 18 October 2017

Published 29 December 2017

Online at http://www.engj.org/

DOI:10.4186/ei.2017.21.7.415 


\section{Introduction}

Generally, fossil fuel was used for industrial and heat process. Then, carbon dioxide and nitrogen oxide were emitted and caused to climate change and greenhouse effects. Many researches were studied about new fuel to replace high carbon fuel such as liquefied petroleum gas (LPG), natural gas [1] and biogas [2]. This study focuses on the combustion of biogas because of wide applications in Thailand. In the past, the combustion of low-carbon fuel such as methane/air, butane/propane/air, and hydrogen/air [3-5] were investigated. In order to reduce the emission, the lean combustion was studied and found the effects of air/fuel ratio owing by thermal-diffusive instability [6-7]. In appearances of lean combustion were shown as lateral movement of flame front and cellular flame due to instability. Flame instability and flame phenomena were experimented and studied by Markstein [8-9]. The flame instability was observed by two main reasons as hydrodynamic instability and diffusive-thermal instability [10]. Hydrodynamic instability is caused by thermal expansion on flame front and heat loss. The diffusive-thermal instability was occurred from preferential diffusion between mass and heat and it can be identified destabilizing and stabilizing instabilities by Lewis number $(\mathrm{Le}<1.0)$ and Le $>1.0$, respectively [11-12]. In the past, hydrocarbon/ hydrogen/ carbon dioxide/ air premixed flames were studied with addition of methane into the process and cellular flame appeared by instability [13]. The study of shape and fluctuation of cellular premixed flames on lean combustion system of $\mathrm{CH}_{4} / \mathrm{O}_{2} / \mathrm{CO}_{2}$ mixtures was studied to investigate the structure of cellular flame due to instability intensity [14]. Moreover, flame shape, fluctuation and cellular size of $\mathrm{CH}_{4} / \mathrm{O}_{2} / \mathrm{CO}_{2}$ mixtures were obtained in lean combustion process [15]. In the previous study, the combustion of $\mathrm{C}_{3} \mathrm{H}_{8} / \mathrm{C}_{4} \mathrm{H}_{10}$ flames on ceramic porous board was analyzed to obtain the cellular flame, size of cellular flame and light emission [16]. The effect of replacement of nitrogen with carbon has brought intrinsic instability and $\mathrm{CO}_{2}$ increased, greater cell size, lower shape peak frequency of power spectral density and more complicated ring were observed [17]. Thus, cellular premixed flames of synthetic biogas on flat burner was investigated to compare the effects of biogas compositions. As the variation of main composition of biogas such as methane $\left(\mathrm{CH}_{4}\right)$ and carbon dioxide $\left(\mathrm{CO}_{2}\right)$, and wide application in power generation and heat process, thus it is interesting to investigate and compare the lean combustion of different composition biogas. The goal in this study is to investigate the characteristic of cellular flame such as cell size, light emission, power spectral density and chaotic behavior with variation of equivalence ratios and firing rates to properly control the lean combustion system of synthetic biogas.

\section{Experimental Setup}

The experimental apparatus shown in Fig. 1 is to study the phenomena of cellular flame. Following the experimental apparatus, Mckenna flat flame burner with $60 \mathrm{~mm}$ in diameter was applied. $\mathrm{CH}_{4}$ and $\mathrm{CO}_{2}$ mixtures flowed into digital mass flow controller from $\mathrm{CH}_{4}, \mathrm{CO}_{2}$ and air compressor to flat burner with fixed total gas flow rate as $45 \mathrm{~L} / \mathrm{min}$. In order to observe the cell size, cellular flame was taken by digital camera (Nikon D7100), measured the light emission by photodiode (HAMAMATSU, S1223-01) and transferred to data logger (HIOKI LR8431-20 Memory HI Logger). The measured intensity of light emission was normalized by Takens (1981) embedding theorem to create the reconstructed attractor that shown in Eq. (1).

$$
\vec{V}(t)=[y(t), y(t+\tau), y(t+2 \tau), \cdots, y(t+(m-1) \tau)]
$$

\section{Methodology}

This experiment was studied with three variations of biogas compositions as agricultural waste, food waste and cow dung as shown in Table 1 . The flow rate was fixed at $45 \mathrm{~L} / \mathrm{min}$ and followed by chemical reaction as in Eq. (2)-(4). In this experiment, the variation of equivalence ratio and variation of firing rate were studied and followed by Table $2-4$.

$$
\begin{aligned}
0.549 \mathrm{CH}_{4}+0.451 \mathrm{CO}_{2}+1.129\left(\mathrm{O}_{2}+3.76 \mathrm{~N}_{2}\right) & \rightarrow \mathrm{CO}_{2}+1.159 \mathrm{H}_{2} \mathrm{O}+4.24 \mathrm{~N}_{2} \\
0.734 \mathrm{CH}_{4}+0.2661 \mathrm{CO}_{2}+1.468\left(\mathrm{O}_{2}+3.76 \mathrm{~N}_{2}\right) & \rightarrow \mathrm{CO}_{2}+1.468 \mathrm{H}_{2} \mathrm{O}+5.52 \mathrm{~N}_{2} \\
0.851 \mathrm{CH}_{4}+0.1487 \mathrm{CO}_{2}+1.703\left(\mathrm{O}_{2}+3.76 \mathrm{~N}_{2}\right) & \rightarrow \mathrm{CO}_{2}+1.703 \mathrm{H}_{2} \mathrm{O}+6.40 \mathrm{~N}_{2}
\end{aligned}
$$




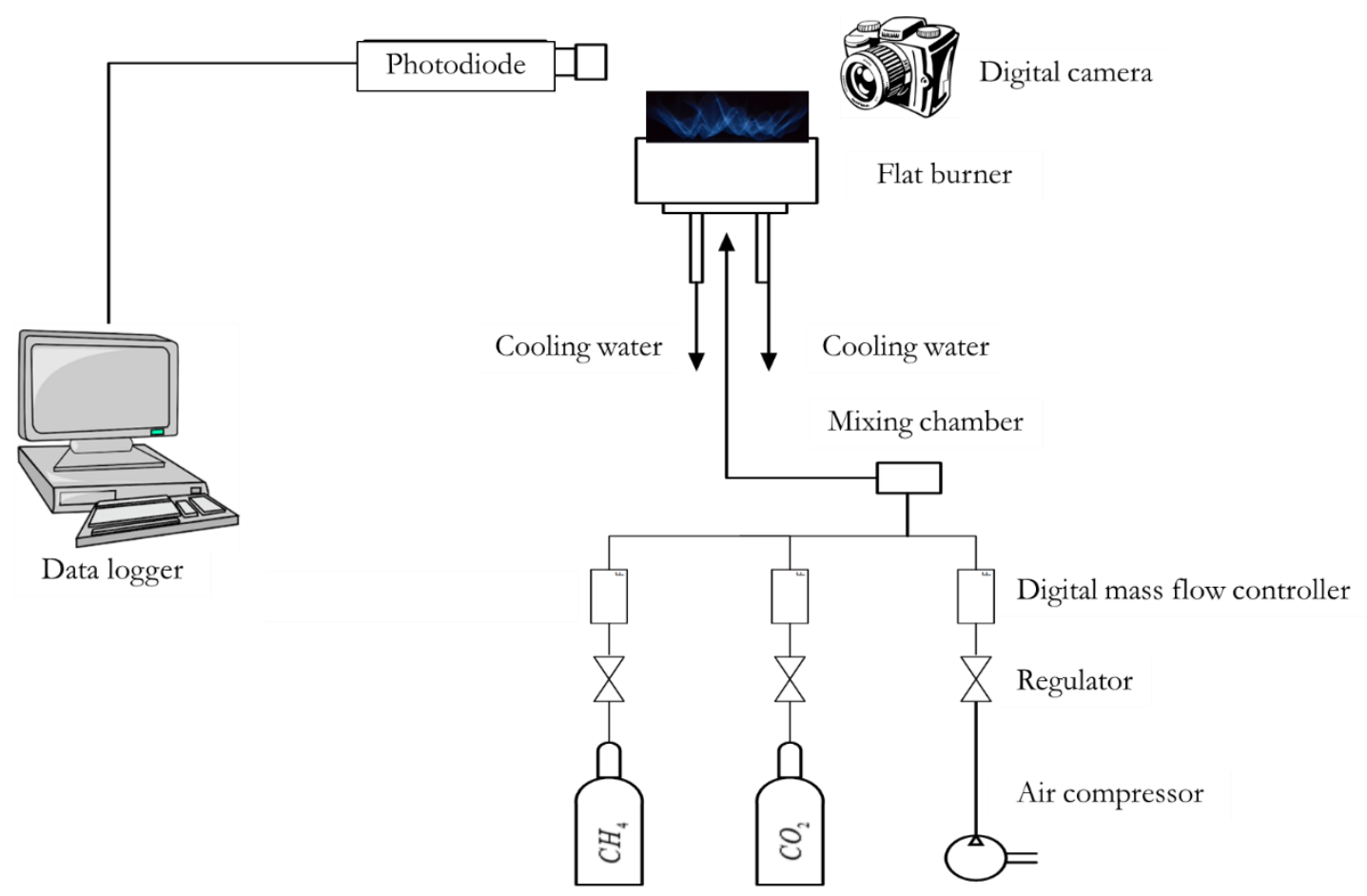

Fig. 1. Experimental apparatus.

Table 1. Biogas compositions.

\begin{tabular}{lcc}
\hline Biogas compositions & $\mathbf{C H}_{4}[\%]$ & $\mathbf{C O}_{2}[\%]$ \\
\hline Agricultural waste & 54.9 & 45.1 \\
Food waste & 73.4 & 26.6 \\
Cow dung & 85.1 & 14.9 \\
\hline
\end{tabular}

Table 2. The variations of synthetic biogas produced from agricultural waste composition.

\begin{tabular}{|c|c|c|c|c|c|c|}
\hline \multirow{2}{*}{$\begin{array}{l}\Phi \\
{[-]}\end{array}$} & \multicolumn{2}{|c|}{$\begin{array}{c}\text { Composition } \\
{[\%]}\end{array}$} & \multicolumn{3}{|c|}{$\begin{array}{c}\text { Gas flow rate } \\
{[\mathrm{L} / \mathrm{min}]}\end{array}$} & \multirow{2}{*}{$\begin{array}{c}\text { Firing rate } \\
{[\mathrm{kW}]}\end{array}$} \\
\hline & $\mathrm{CH}_{4}$ & $\mathrm{CO}_{2}$ & $\mathrm{CH}_{4}$ & $\mathrm{CO}_{2}$ & Air & \\
\hline 0.65 & 54.9 & 45.1 & 2.6 & 2.2 & 40.2 & 2.65 \\
\hline 0.70 & 54.9 & 45.1 & 2.8 & 2.3 & 39.9 & 2.80 \\
\hline 0.75 & 54.9 & 45.1 & 3.0 & 2.5 & 39.5 & 3.03 \\
\hline 0.80 & 54.9 & 45.1 & 3.2 & 2.6 & 39.2 & 3.17 \\
\hline 0.85 & 54.9 & 45.1 & 3.3 & 2.7 & 39.0 & 3.29 \\
\hline
\end{tabular}

Table 3. The variations of synthetic biogas produced from food waste composition.

\begin{tabular}{|c|c|c|c|c|c|c|}
\hline \multirow{2}{*}{$\begin{array}{l}\Phi \\
{[-]}\end{array}$} & \multicolumn{2}{|c|}{$\begin{array}{c}\text { Composition } \\
{[\%]}\end{array}$} & \multicolumn{3}{|c|}{$\begin{array}{c}\text { Gas flow rate } \\
{[\mathrm{L} / \mathrm{min}]}\end{array}$} & \multirow{2}{*}{$\begin{array}{c}\text { Firing rate } \\
{[\mathrm{kW}]}\end{array}$} \\
\hline & $\mathrm{CH}_{4}$ & $\mathrm{CO}_{2}$ & $\mathrm{CH}_{4}$ & $\mathrm{CO}_{2}$ & Air & \\
\hline 0.75 & 73.4 & 26.6 & 3.1 & 1.1 & 40.8 & 2.51 \\
\hline 0.80 & 73.4 & 26.6 & 3.3 & 1.2 & 40.5 & 2.70 \\
\hline 0.85 & 73.4 & 26.6 & 3.5 & 1.3 & 40.2 & 2.90 \\
\hline
\end{tabular}


Table 4. The variations of synthetic biogas produced from cow dung composition.

\begin{tabular}{|c|c|c|c|c|c|c|}
\hline \multirow{2}{*}{$\begin{array}{c}\Phi \\
{[-]}\end{array}$} & \multicolumn{2}{|c|}{$\begin{array}{c}\text { Composition } \\
{[\%]} \\
\end{array}$} & \multicolumn{3}{|c|}{$\begin{array}{c}\text { Gas flow rate } \\
{[\mathrm{L} / \mathrm{min}]}\end{array}$} & \multirow{2}{*}{$\begin{array}{c}\text { Firing rate } \\
{[\mathrm{kW}]}\end{array}$} \\
\hline & $\mathrm{CH}_{4}$ & $\mathrm{CO}_{2}$ & $\mathrm{CH}_{4}$ & $\mathrm{CO}_{2}$ & Air & \\
\hline 0.75 & 85.1 & 14.9 & 3.1 & 3.1 & 3.1 & 2.12 \\
\hline 0.80 & 85.1 & 14.9 & 3.3 & 3.3 & 3.3 & 2.35 \\
\hline 0.85 & 85.1 & 14.9 & 3.5 & 3.5 & 3.5 & 2.44 \\
\hline 0.90 & 85.1 & 14.9 & 3.7 & 3.7 & 3.7 & 2.54 \\
\hline 0.95 & 85.1 & 14.9 & 3.9 & 3.9 & 3.9 & 2.76 \\
\hline
\end{tabular}

\subsection{Lewis Number}

There are three basic phenomena of intrinsic instability as hydrodynamic instability, body-force instability and diffusive-thermal instability. Cellular flame is caused by hydrodynamic and diffusive-thermal instability which affect to flame stabilization due to thermal and mass diffusivity. The ratio between thermal diffusivity $(\alpha)$ and mass diffusivity $(D)$ is known as Lewis number $(L e)$ which is shown in Eq. (5). When Le $<1$, premixed flame is effected by destabilizing influence. When Le $>1$, premixed flame is effected by stabilizing influence.

$$
L e=\frac{\alpha}{D}
$$

\subsection{Cell Size}

The definition of cell size is the distance between top of cellular flame front as shown in Fig. 2. The study was investigated to illustrate the instability intensity such a cell size of cellular flame which can be described by Eq. (6).

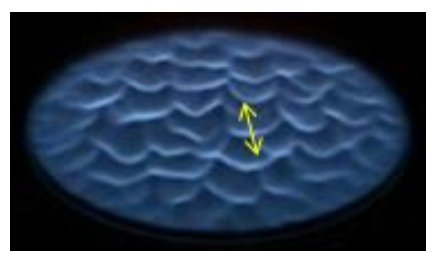

Fig. 2. Definition of cell size [17].

$$
\mathrm{X}_{\mathrm{a}}=\mathrm{X}_{\mathrm{p}}\left(\mathrm{D}_{\mathrm{a}} / \mathrm{D}_{\mathrm{p}}\right)
$$

$\mathrm{X}_{\mathrm{a}}=$ Actual Cell size

$\mathrm{X}_{\mathrm{p}}=$ Cell size from illustrate

$\mathrm{D}_{\mathrm{a}}=$ Actual Burner diameter

$\mathrm{D}_{\mathrm{p}}=$ Burner diameter from illustrate

\subsection{Power Spectral Density}

The light emission detected from photo-diode was analyzed by Fast Fourier Transform (FFT) to obtain the shaft peak frequency $\left(f_{1}\right)$. Moreover, the shaft peak frequency had the relationship with time delay $(\tau)$ as shown in Eq. (7).

$$
\tau=\frac{2}{f_{1}}
$$




\subsection{Reconstructed Attractor Analysis}

The reconstructed attractor was analyzed by Takens' embedding theorem with time delay obtained from power spectral density. The embedding, $m=3$ was set in vector $\vec{V}(t)$ followed by Eq. (8) to create attractor. The reconstructed attractor was analyzed to investigate the effects on biogas combustion flames induced by variation of compositions.

$$
\vec{V}(t)=[y(t), y(t+\tau), y(t+2 \tau), \cdots, y(t+(m-1) \tau)]
$$

\section{Results}

This study, the equivalence ratio and firing rate in biogas combustion from agricultural waste, food waste and cow dung, were investigated. The main compositions of biogas are $\mathrm{CH}_{4}$ and $\mathrm{CO}_{2}$ which is different in above three biogas compositions. The combustion of biogas was experimented and the cell size, power spectral density and reconstructed attractor were obtained. The results of variation of equivalence ratio were obtained in the range of cellular flame in each cases. It was shown in Table. 5. The combustion of biogas from agricultural waste was found cellular flame in range between $\Phi=0.75-1.00$ and blow off was occurred when $\Phi<0.75$, from food waste was found cellular flame in range between $\Phi=0.70-0.90$ and blow off was occurred when $\Phi<0.70$ and from cow dung were found cellular flame in range between $\Phi=0.65-0.80$ and blow off was occurred when $\Phi<0.65$.

Table 5. Ranges of cellular flame in each compositions.

\begin{tabular}{cccc}
\hline Biogas composition & $\mathbf{C H}_{4}[\%]$ & $\mathbf{C O}_{2}[\mathbf{\%}]$ & Cellular Flame \\
\hline Agricultural waste & 54.9 & 45.1 & $\Phi=0.75-1.00$ \\
Food waste & 73.4 & 26.6 & $\Phi=0.70-0.90$ \\
Cow dung & 85.1 & 14.9 & $\Phi=0.65-0.80$ \\
\hline
\end{tabular}

\subsection{Lewis Number}

Following the variation of synthetic biogas compositions, Lewis numbers become higher when equivalence ratios increase as shown in Table 6. When equivalence ratios increased between 0.75 and 0.85 , Lewis number increased from 1.75 to $2.04,1.40$ to 1.64 and 1.22 to 1.42 for agricultural waste composition, food waste and cow dung compositions, respectively. It was because of equivalence ratio near to stoichiometry bring about higher ratio between thermal and mass diffusivity.

Table 6. Lewis number affected by variations of synthetic biogas compositions.

\begin{tabular}{|c|c|c|c|c|c|c|c|c|c|}
\hline \multirow[t]{2}{*}{$\begin{array}{c}\boldsymbol{\Phi} \\
{[-]}\end{array}$} & \multicolumn{2}{|c|}{$\begin{array}{c}\text { Agricultural waste } \\
\text { composition } \\
{[\%]}\end{array}$} & \multirow[t]{2}{*}{$\begin{array}{l}\text { Le } \\
{[-]}\end{array}$} & \multicolumn{2}{|c|}{$\begin{array}{c}\text { Food waste } \\
\text { composition } \\
{[\%]}\end{array}$} & \multirow[t]{2}{*}{$\begin{array}{l}\text { Le } \\
{[-]}\end{array}$} & \multicolumn{2}{|c|}{$\begin{array}{c}\text { Cow dung } \\
\text { composition } \\
{[\%]}\end{array}$} & \multirow[t]{2}{*}{$\begin{array}{l}\text { Le } \\
{[-]}\end{array}$} \\
\hline & $\mathrm{CH}_{4}$ & $\mathrm{CO}_{2}$ & & $\mathrm{CH}_{4}$ & $\mathrm{CO}_{2}$ & & $\mathrm{CH}_{4}$ & $\mathrm{CO}_{2}$ & \\
\hline 0.75 & 54.9 & 45.1 & 1.75 & 73.4 & 26.6 & 1.40 & 85.1 & 14.9 & 1.22 \\
\hline 0.80 & 54.9 & 45.1 & 1.90 & 73.4 & 26.6 & 1.52 & 85.1 & 14.9 & 1.32 \\
\hline 0.85 & 54.9 & 45.1 & 2.04 & 73.4 & 26.6 & 1.64 & 85.1 & 14.9 & 1.42 \\
\hline
\end{tabular}

\subsection{Cell Size of Cellular Flame}

When the equivalence ratio increased, the cell size was lower due to increase of stability. Table 7 and Fig. 3 show the equivalence ratio decreases from 0.85 to 0.75 , the cell sizes were increased from $9.20 \mathrm{~mm}$ to 10.8 $\mathrm{mm}$ for agricultural waste composition, increased from $5.84 \mathrm{~mm}$ to $8.86 \mathrm{~mm}$ for food waste composition and increased from $4.95 \mathrm{~mm}$ to $7.28 \mathrm{~mm}$ for cow dung composition. As the results, agricultural waste composition was more unstable than food waste and cow dung in respectively due to increase of stability induced by $\mathrm{CH}_{4}$ concentration. 
In addition, firing rates were varied from $2.50,2.65$ and $2.80 \mathrm{~kW}$ then the cell size was smaller. Figure 4 shows that the decrease of firing rate affected to increase of cell size of biogas from food waste as $6.45 \mathrm{~mm}$ to $8.86 \mathrm{~mm}$. However, during firing rate variation, cell size from cow dung composition was not changed and the blow-off flame was occurred for agricultural waste composition.

Table 7. Cell size of cellular flames with variation of equvalence ratio for agricultural waste, food waste and cow dung compositions.

\begin{tabular}{lccc}
\hline Bio gas composition & \multicolumn{3}{c}{ Cell size $[\mathrm{mm}]$} \\
\cline { 2 - 4 } & $\mathbf{\Phi = 0 . 7 5}$ & $\mathbf{\Phi = 0 . 8 0}$ & $\mathbf{\Phi = 0 . 8 5}$ \\
\hline Agricultural waste & 10.8 & 9.36 & 9.20 \\
Food easte & 8.86 & 6.69 & 5.84 \\
Cow dung & 7.28 & 4.95 & Flat flame \\
\hline
\end{tabular}

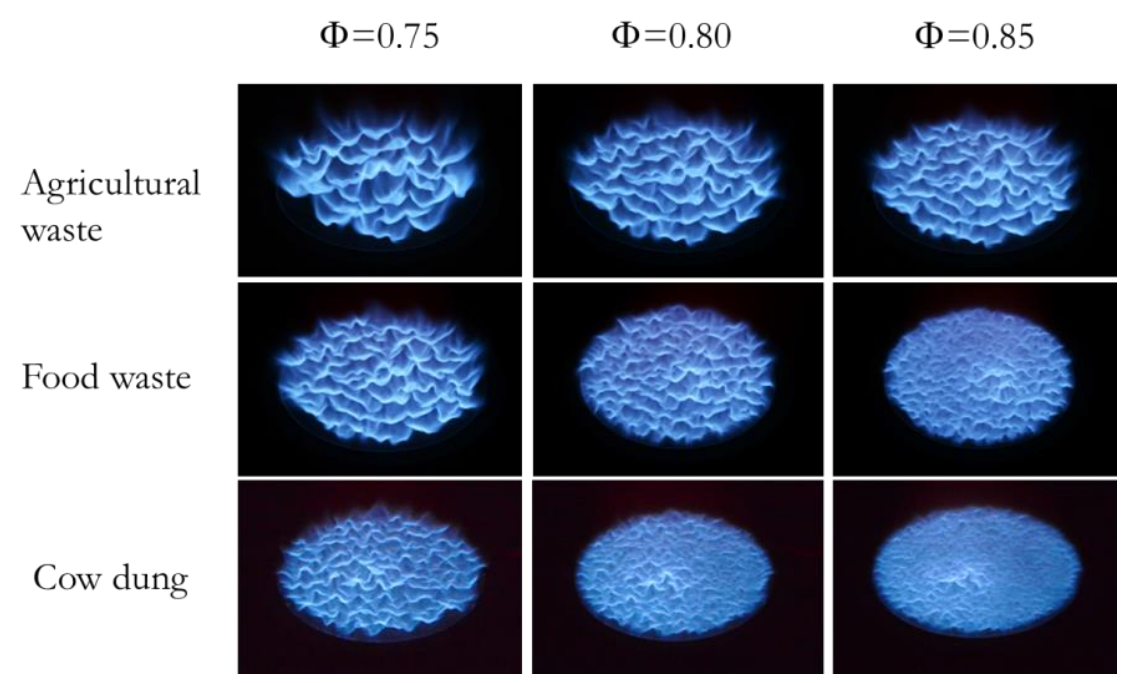

Fig. 3. Photos of cellular flames with variation of equvalence ratio for agricultural waste, food waste and cow dung compositions.

$$
\text { F.R. }=2.50 \mathrm{~kW} \quad \text { F.R. }=2.65 \mathrm{~kW} \quad \text { F.R. }=2.80 \mathrm{~kW}
$$

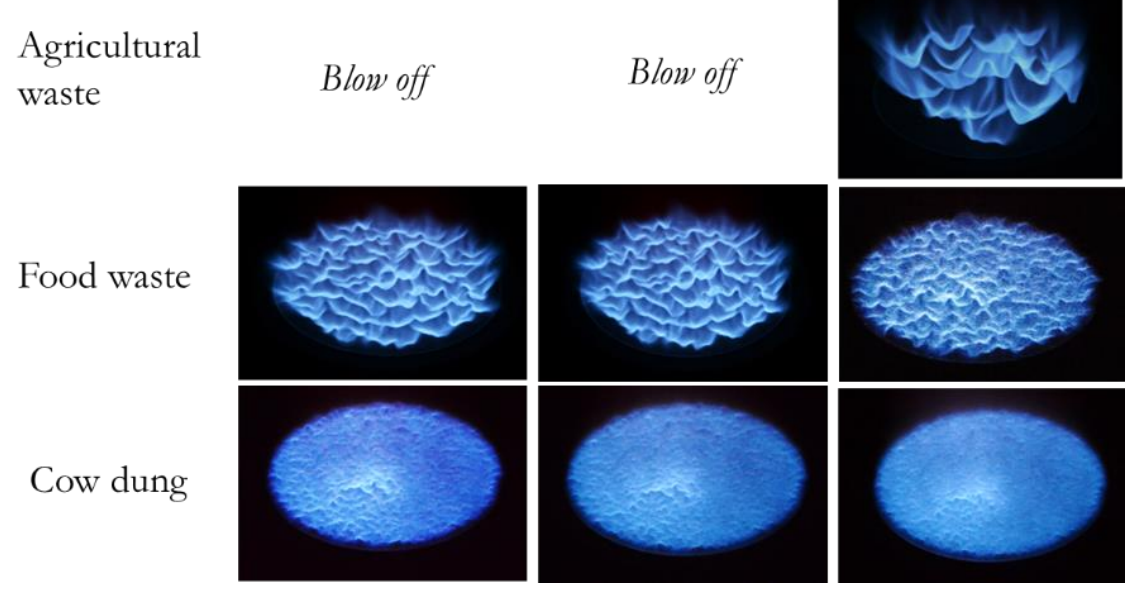

Fig. 4. Photos of cellular flames with variation of firing rate for agricultural waste, food waste and cow dung compositions. 


\subsection{Power Spectral Density}

Figure 5 shows that the equivalence ratio of biogas combustion from agricultural waste composition increases, the sharp peak frequency from power spectral density was higher due to increase of stability. At the same equivalence ratio, $\Phi=0.80$, the sharp peak frequency from power spectral density from cow dung composition is higher compared to agricultural waste and food waste compositions due to stability intensity as shown in Fig. 6.

For food waste composition, when the firing rate decreased from $2.90 \mathrm{~kW}$ until $2.70 \mathrm{~kW}$ then the sharp peak frequency from power spectral density was lowered as shown in Fig. 7. The results also found that at the firing rate $2.80 \mathrm{~kW}$ in Fig. 8, the highest sharp peak frequency of power spectral density was obtained from cow dung composition due to the increase of energy.
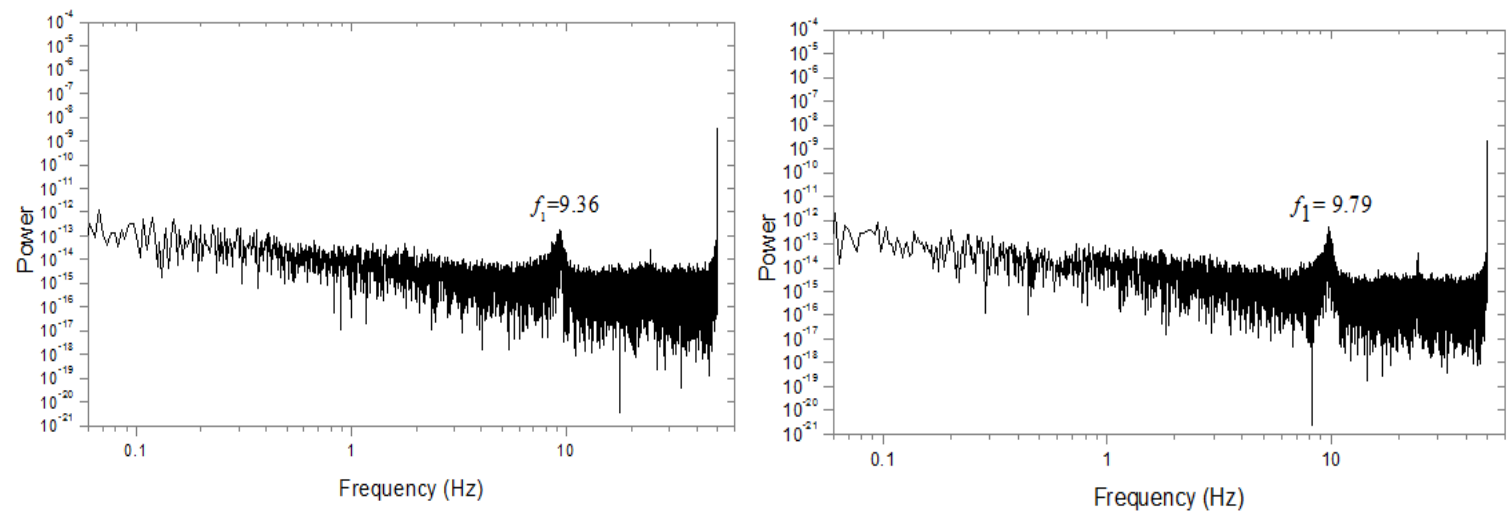

Fig. 5. Power spectral density of agricultural waste composition at (a) $\Phi=0.75$ and (b) $\Phi=0.80$.
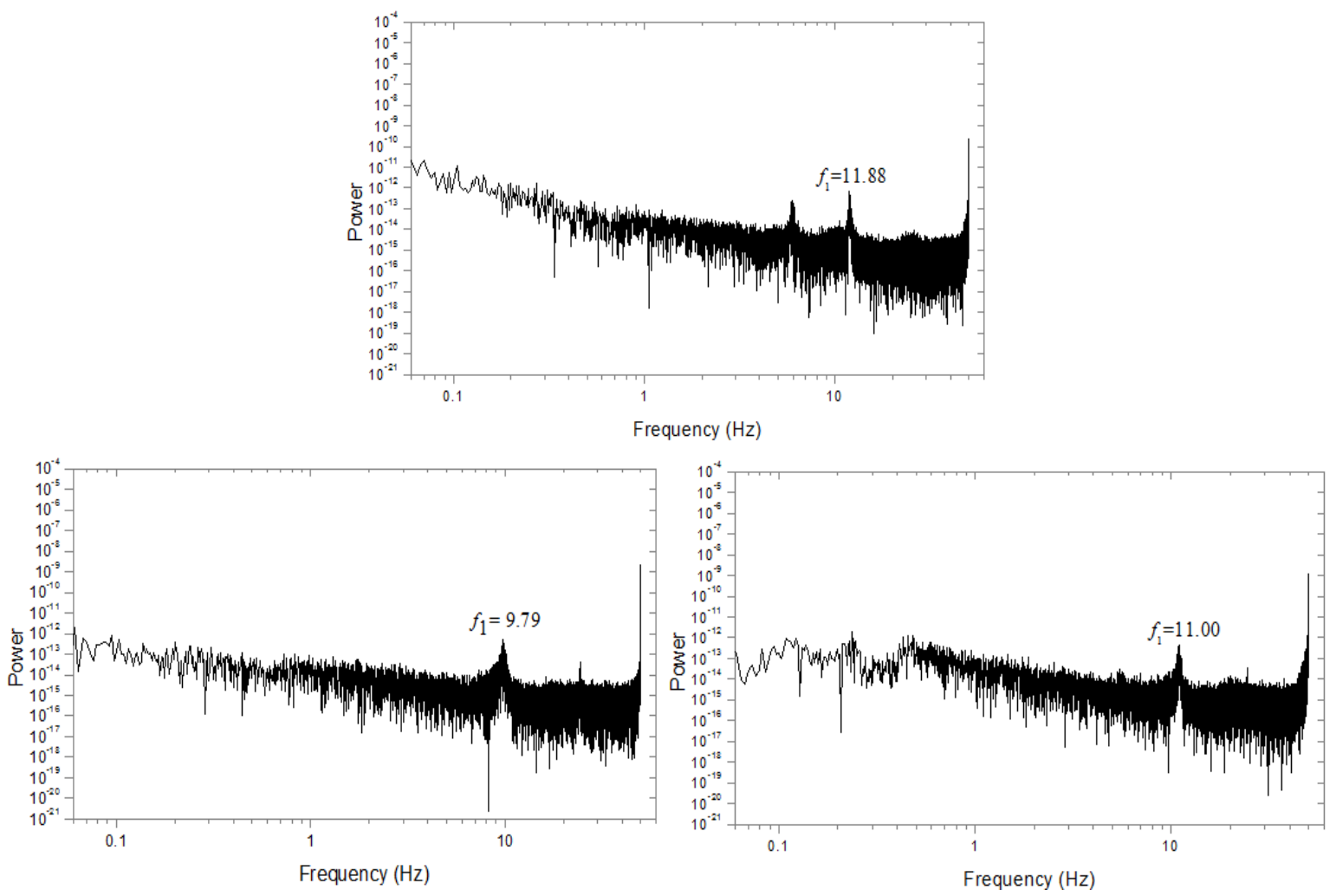

Fig. 6. Power spectral density at $\Phi=0.80$ for (a) cow dung composition, (b) agricultural waste composition and (c) food waste composition. 

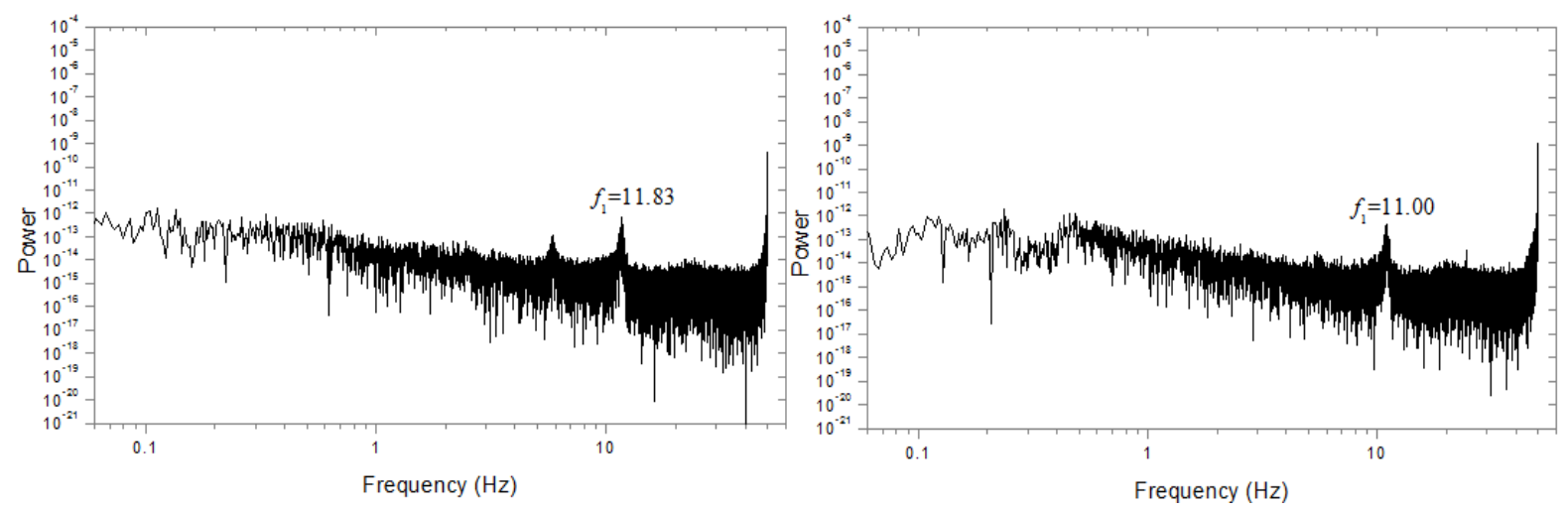

Fig. 7. Power spectral density of food waste composition at (a) F.R $=2.90 \mathrm{~kW}$ and (b) F.R $=2.70 \mathrm{~kW}$.

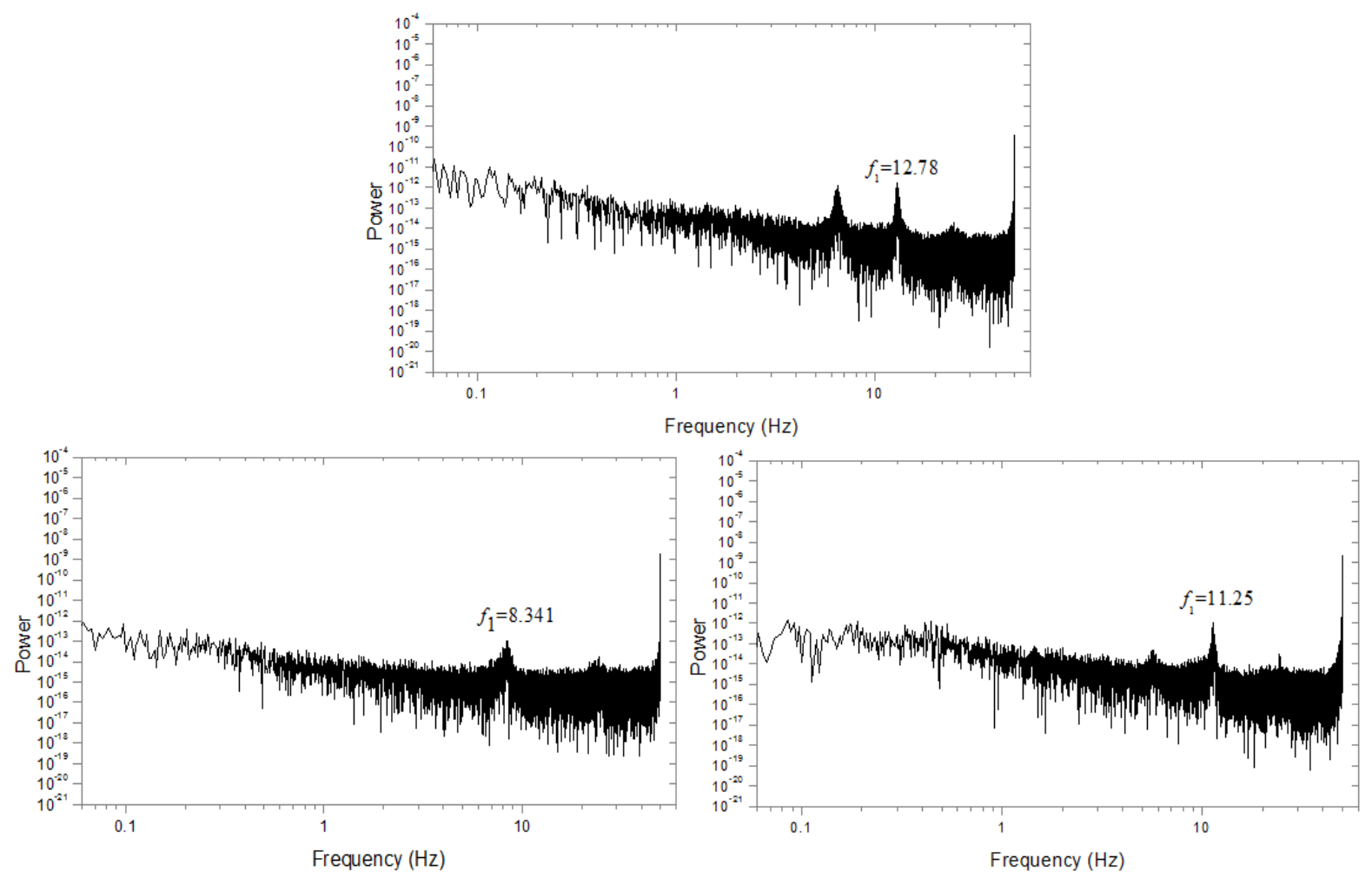

Fig. 8. Power spectral density at F.R $=2.80 \mathrm{~kW}$ for (a) cow dung composition, (b) agricultural waste composition and (c) food waste composition.

\subsection{Reconstructed Attractor}

As the previous results, the shaft peak frequency was calculated to obtain the time-delay to create the reconstructed attractor in three-dimension. Fig. 9 show that the equivalence ratio of biogas combustion from agricultural waste composition increases, the size of reconstructed attractor becomes smaller due to decrease of instability. At the same equivalence ratio, $\Phi=0.80$, the attractor from cow dung composition is the greatest compared to agricultural waste and food waste compositions due to stability intensity as shown in Fig. 10.

For food waste composition, when the firing rate decreased from $2.80 \mathrm{~kW}$ to $2.50 \mathrm{~kW}$, then the reconstructed attractor was greater as illustrated in Fig. 11. Moreover, Figure 12 shows the firing rate of 2.80 $\mathrm{kW}$, the smallest attractor was obtained from cow dung composition due to the increase of energy induced higher stability. 

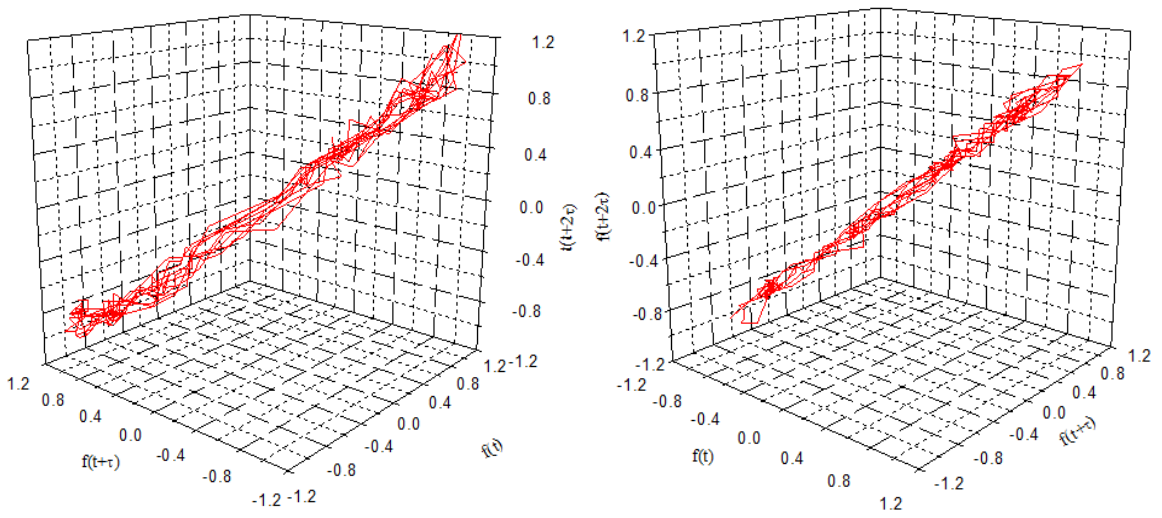

Fig. 9. Reconstructed attractor of agricultural waste composition at (a) $\Phi=0.75$ and (b) $\Phi=0.80$.
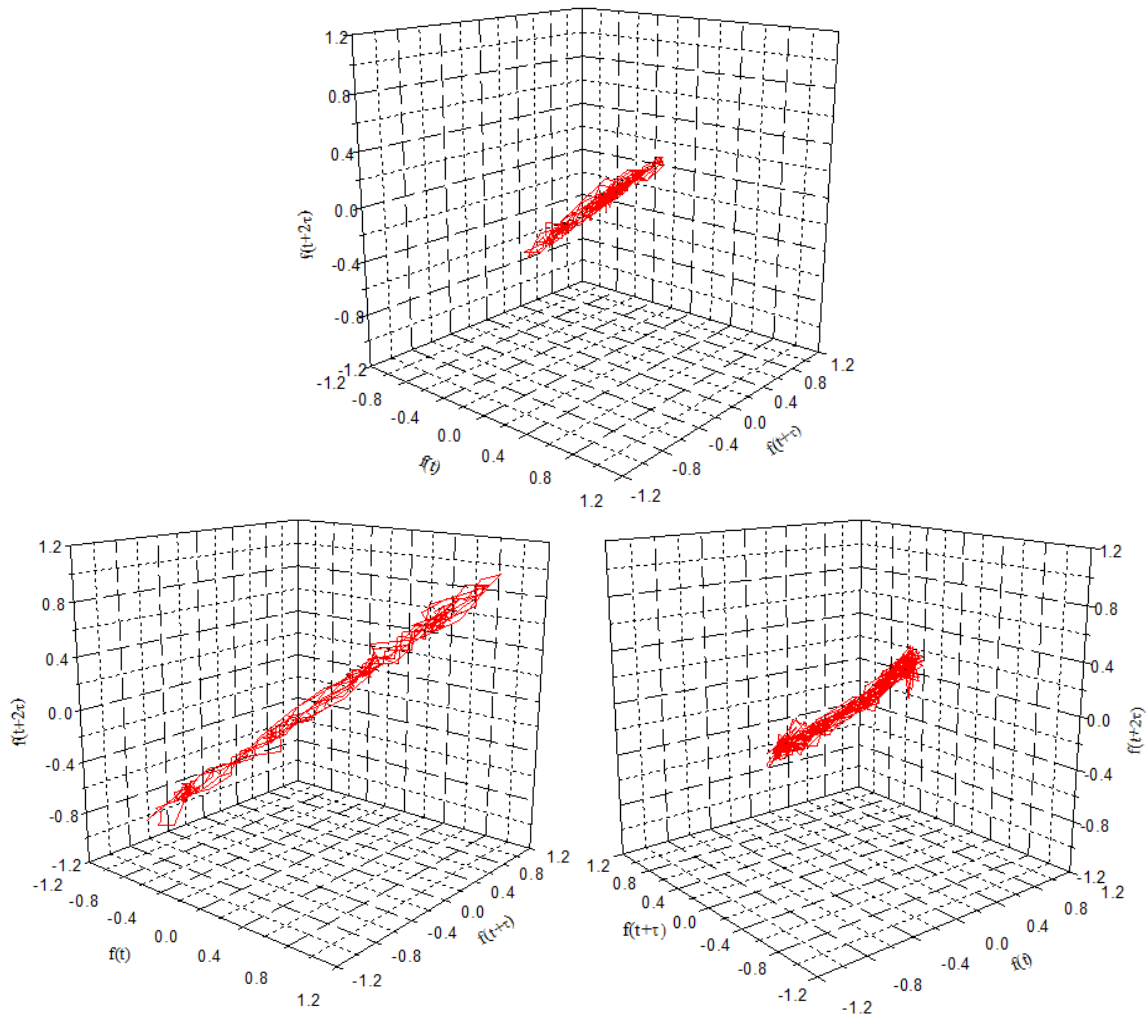

Fig. 10. Reconstructed attractor at $\Phi=0.80$ for (a) cow dung composition, (b) agricultural waste composition and (c) food waste composition.
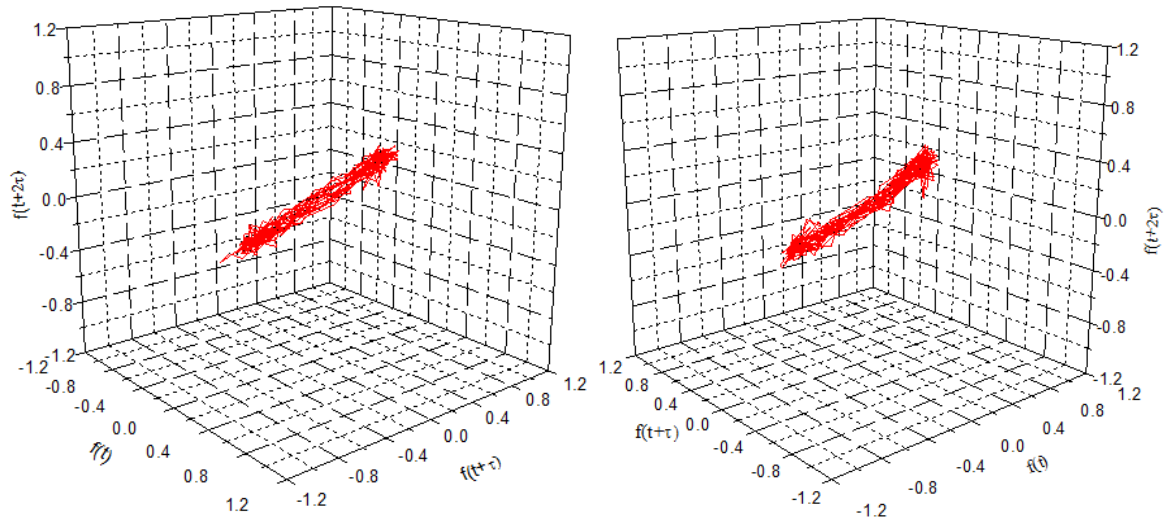

Fig. 11. Reconstructed attractor of food waste composition at (a) F.R $=2.90 \mathrm{~kW}$ and (b) F.R $=2.70 \mathrm{~kW}$. 

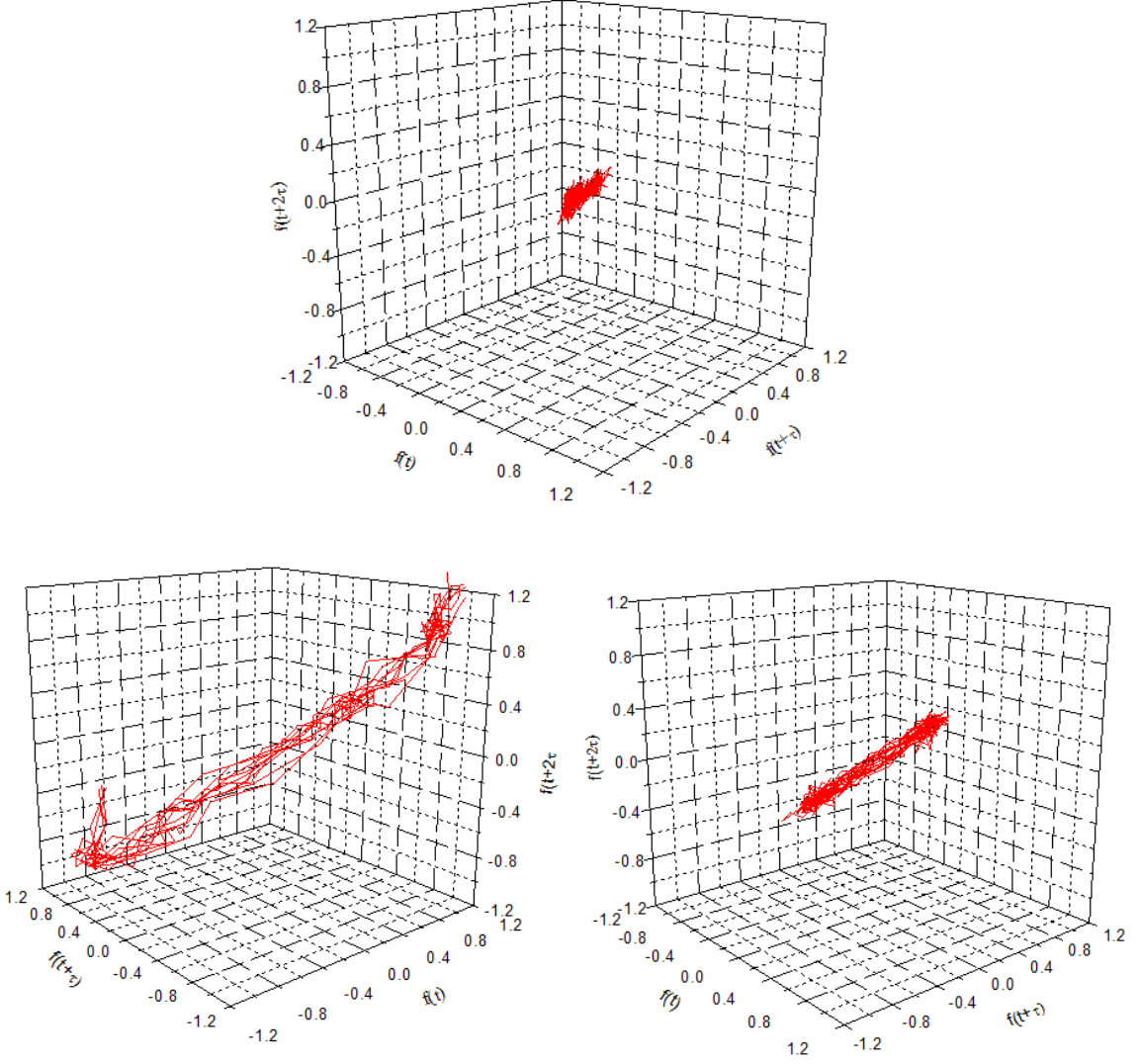

Fig. 12. Reconstructed attractor of cow dung composition at F.R $=2.80 \mathrm{~kW}$ for (a) cow dung composition, (b) agricultural waste composition and (c) food waste composition.

\section{Conclusions}

To compare the effects of biogas compositions, cellular premixed flames of synthetic biogas on flat burner was investigated. As the variation of main composition of biogas such as methane $\left(\mathrm{CH}_{4}\right)$ and carbon dioxide $\left(\mathrm{CO}_{2}\right)$, the biogas produced from agricultural waste (54.9:45.1), food waste (73.4:26.6) and cow dung (85.1:14.9) were used to investigate for this study. The cell size, light emission detected by photodiode, power spectral density created by Fast Fourier and attractor constructed by Taken's embedding theorem were analyzed. The results showed that agricultural waste, food waste and cow dung compositions yield the cellular flame between $\Phi=0.75-1.00, \Phi=0.70-0.90$ and $\Phi=0.65-0.80$, respectively. In addition, the blown off flames were also observed at $\Phi<0.75, \Phi<0.70$ and $\Phi<0.65$ for agricultural waste, food waste and cow dung compositions, respectively. When equivalence ratio was smaller, the firing rate become lower, the reconstructed attractor was larger owing to diffusive-thermal instability. The results showed the variation of synthetic biogas of equivalence ratio and firing rate affected to cellular flames owing to the intrinsic instability. In addition, equivalence ratio near to stoichiometry bring about higher Lewis number due to increase of ratio between thermal and mass diffusivity. Thus, it was concluded that small cell size, higher light emission and higher shaft peak frequency including narrow unstable range obtained by the combustion of biogas produced from cow dung was more stable compared to biogas from agricultural waste and food waste compositions.

\section{Acknowledgement}

The authors would like to thank to Office of the Higher Education Commission, Thailand Research Fund (TRF: IRG5780005), for financial support and Department of Mechanical Engineering, Faculty of Engineering, King Mongkut's University of Technology Thonburi (KMUTT) for facility supports. 


\section{References}

[1] Energy Policy and Planning Office, Energy Statistics of Thailand. 2013.

[2] Department of Industrial Works, Manual for Design, Produce, Quality Control and Uses of Biogas for Industrial Works, 1st ed. Bangkok: Department of Industrial Works, Thailand, 2010.

[3] M. Izumikawa, T. Mitani, and T. Niioka, "Experimental study on cellular flame propagation of blend fuels," Combustion and Flame, vol. 73, pp. 207-214, 1988.

[4] M. el-Hamdi, M. Gorman, and K. A. Robbins, "Deterministic chaos in laminar premixed flames: Experimental classification of chaotic dynamics," Combustion Science and Technology, vol. 94, pp. 87-101, 1993.

[5] S. Kadowaki and N. Ohkura, "Time series analysis on the emission of light from methane-air lean premixed flames: Diagnostics of the flame instability," Transaction of Japan Society of Aeronautical and Space Science, vol. 51, no. 173, pp. 133-138, 2008.

[6] M. Abdulwahid, K. M. Saqr, M. M. Sies, and H. Ujir, "Diffusive thermal instabilities of $\mathrm{C}_{4} \mathrm{H}_{10}-\mathrm{C}_{3} \mathrm{H}_{8} /$ air laminar premixed flames," Diffusion Fundamentals, vol. 9, no. 8, pp.1-8, 2009.

[7] R. A. Strehlow, Combustion Fundamentals. Mc Graw-Hill, 1985, pp. 290-296.

[8] G. H. Markstein, "Instability phenomena in combustion waves," in Proceedings of the Combustion Institute, 1952, pp. 44-59.

[9] G. H. Markstein, Non-steady Flame Propagation. Oxford: Paragon, 1964, p. 75.

[10] F. A. Williams, Combustion Theory, 2nd ed. Redwood, CA: Addison-Wesley, 1985, pp. 349-365.

[11] P. Clavin, "Dynamic behavior of premixed flame fronts in laminar and turbulent flows," Progress in Energy Combustion Science, vol. 11, no. 1, pp. 1-59, 1985.

[12] G. I. Sivashinsky, "On the intrinsic dynamics of premixed flames," Philosophical Transaction of the Royal Society, Ser. A, vol. 332, pp.135-148, 1990.

[13] M. V. Tran, P. Jeong, S. K. Jeong, B. K. Oh, H. Y. Jin, and I. K. Sanf, "Experiment study on cellular instabilities in hydrocarbon/hydrogen/carbon monoxide-air premixed flames," International Journal of Hydrogen Energy, vol. 36, pp. 6914-6924, 2011.

[14] A. K. Alexander and V. D. Igor, "Measurement of propagation speeds in adiabatic cellular premixed flames of $\mathrm{CH}_{4}+\mathrm{O}_{2}+\mathrm{CO}_{2}$," Experimental Thermal and Fluid Science, vol. 29, pp. 901-907, 2005.

[15] S. Kadowaki and H. Ohashi, "Shape and fluctuation of cellular flame premixed flames: Lean combustion system of $\mathrm{CH}_{4} / \mathrm{O}_{2} / \mathrm{CO}_{2}$ mixtures," Journal of Visualization, vol. 16, no. 1, pp. 5-8, 2012.

[16] A. Kaewpradap and J. Sumrerng, "Intrinsic instability of $\mathrm{C}_{3} \mathrm{H}_{8}-\mathrm{C}_{4} \mathrm{H}_{10}$ /air flames on ceramic porous board," presented at The $6^{\text {th }}$ TSME International Conference on Mechanical Engineering, Petchburi, Thailand, 2015.

[17] A. Kaewpradap and S. Kadowak, "Instability influenced by $\mathrm{CO}_{2}$ and equivalence ratio in oxyhydrogen flames on flat burner," Combustion Science and Technology, vol. 189, no. 3, pp. 438-452, 2017. 